\title{
Millimolar concentrations of free magnesium enhance exocytosis from permeabilized rat pheochromocytoma (PC 12) cells
}

\author{
U. Wegenhorst, M. Gratzl, K.J. Föhr and G. Ahnert-Hilger \\ Abteilung Anatomie und Zellbiologie der Universität Ulm, Ulm (F.R.G.)
}

(Received 9 June 1989; Revised version received 20 July 1989; Accepted 26 July 1989)

Key words: Permeabilization; Rat pheochromocytoma; Exocytosis; Calcium; Magnesium

The role of $\mathrm{Mg}^{2+}$ during the final steps of exocytosis was investigated using rat pheochromocytoma cells (PC12) permeabilized with bacterial pore forming toxins. Concentrations of free $\mathrm{Mg}^{2+}$ between 0.2 and $2 \mathrm{mM}$ slightly lowered the basal but greatly enhanced the [3 $\mathrm{H}]$ dopamine release elicited by $8 \mu \mathrm{M}$ free $\mathrm{Ca}^{2+}$. Maximal effects were obtained at approximately $1 \mathrm{mM}$ free $\mathrm{Mg}^{2+}$. At higher concentrations $\mathbf{M g}^{2+}$ was less potent. Similar effects of $\mathbf{M g}^{2+}$ were obtained in cells permeabilized either for small molecules (by $\alpha$-toxin) or for large ones (by streptolysin $O$ ). It is concluded that millimolar concentrations of cytoplasmic $\mathrm{Mg}^{2+}$ play an important role in $\mathrm{Ca}^{2+}$ triggered exocytosis.

Presently, the role of $\mathrm{Mg}^{2+}$ during intracellular processes is poorly understood. Many intracellular reactions depend on a sufficient supply of this divalent cation but exact data on the free $\mathrm{Mg}^{2+}$ concentrations in the cytoplasm, its regulation and role during complex processes such as exocytosis are lacking. It has been reported that fairly high concentrations of $\mathrm{Mg}^{2+}$ inhibit $\mathrm{Ca}^{2+}$-induced exocytosis from electrically permeabilized bovine adrenal chromaffin cells [15]. In these cells however, exocytosis requires the presence of ATP and $\mathrm{Mg}^{2+}[7,15]$ which does not allow a clear distinction between effects of free $\mathrm{Mg}^{2+}$ alone and $\mathrm{Mg}^{2+}$ in concert with ATP. In the rat pheochromocytoma cell line $\mathrm{PC12}$ [14] exocytosis can be stimulated with $\mathrm{Ca}^{2+}$ alone, in the absence of $\mathrm{Mg}^{2+}$ and ATP [2-5]. Thus, using this cell line the effects of $\mathrm{Mg}^{2+}$ can be investigated more precisely.

Stock cultures of pheochromocytoma cells ( $\mathrm{PC1} 2)$ were kindly provided by $\mathrm{H}$. Thoenen, Max Planck Institut für Psychiatrie, Martinsried, F.R.G. The cells were cultivated as given earlier $[1,5]$. Permeabilization of the cells was achieved by poreforming bacterial toxins [5,9]. $\alpha$-toxin from Staphylococcus aureus was prepared as described [16]. Streptolysin $O$ from $\beta$-hemolytic streptococci (SLO) was prepared [8]

Correspondence: G. Ahnert-Hilger, Abt. Anatomie u. Zellbiologie, Universität Ulm, Postfach 4066, 7900 Ulm, F.R.G. 
and kindly provided by S. Bhakdi (Institut für Mikrobiologie der Universität Gießen). The concentrations of both toxins are given in hemolytic units $(\mathrm{HU} / \mathrm{ml})$ obtained with $2.5 \%$ rabbit erythrocytes $[5,16]$. The free concentrations of $\mathrm{Ca}^{2+}$ and $\mathrm{Mg}^{2+}$ were calculated using the stability constants given [17] and controlled by ionselective electrodes. The $\mathrm{Mg}^{2+}$-sensitive carrier (ETH 5214) and the $\mathrm{Ca}^{2+}$-sensitive carrier (ETH 129) were kindly provided by W. Simon, ETH Zurich, Switzerland. They were incorporated into polyvinylchloride membranes as described $[6,18]$. Exocytosis was triggered by $\mathrm{Ca}^{2+}$ in the presence of different concentrations of free $\mathrm{Mg}^{2+}$ in $\mathrm{KG}$ (potassium glutamate) buffer containing (mM): KG 150, PIPES 10 , EGTA (ethylenglycol-bis $\left(\beta\right.$ aminoethylether)- $N, N, N^{\prime}, N^{\prime}$-tetraacetic acid) 0.5 , NTA (nitriloacetic acid) 5, pH 7.2 adjusted with $\mathrm{KOH}$. Further details are given in the Legends of the figures.

One problem encountered in the analysis of effects of low $(\mu \mathrm{M})$ concentrations of free $\mathrm{Ca}^{2+}$ in the presence of high (mM) concentrations of free $\mathrm{Mg}^{2+}$ is the precise control of both concentrations of these ions. To overcome this, all the buffers used contained chelators for $\mathrm{Mg}^{2+}$ and $\mathrm{Ca}^{2+}$ (see above). In addition, their free $\mathrm{Ca}^{2+}$ and $\mathrm{Mg}^{2+}$ concentrations were measured by ion-specific electrodes [6, 18].

The high selectivity of the electrodes used allowed us to analyze micromolar amounts of free $\mathrm{Ca}^{2+}$ in the presence of millimolar amounts of free $\mathrm{Mg}^{2+}$. Thus the effects of $\mathrm{Mg}^{2+}$ on $\mathrm{Ca}^{2+}$-stimulated exocytosis observed here are directly correlated to its free concentrations. Representative determinations of $\mathrm{Ca}^{2+}$ and $\mathrm{Mg}^{2+}$ obtained by the electrodes in the buffers used are listed in Table I.

$\mathrm{Mg}^{2+}$ exhibited two effects on exocytosis from $\alpha$-toxin permeabilized PC12 cells.

\section{TABLE I}

CALCULATED VALUES FOR THE FREE $\mathrm{Ca}^{2+}$ AND $\mathrm{Mg}^{2+}$ CONCENTRATIONS AND THEIR CONTROL BY ION-SPECIFIC ELECTRODES

A: Determination of the free $\mathrm{Ca}^{2+}$ concentration in the presence of various amounts of free $\mathrm{Mg}^{2+}$. $\mathrm{B}$ : Determination of the free $\mathrm{Mg}^{2+}$ concentration in the absence or presence of $8 \mu \mathrm{M} \mathrm{free} \mathrm{Ca}^{2+} . \mathrm{Mg}^{2+}$ and $\mathrm{Ca}^{2+}$ were added to $\mathrm{KG}$ buffer to give the calculated free $\mathrm{Mg}^{2+}$ or $\mathrm{Ca}^{2+}$ concentrations. The $\mathrm{pH}$ was adjusted to 7.2 and the concentrations of free $\mathrm{Mg}^{2+}$ and $\mathrm{Ca}^{2+}$ were checked by the respective electrodes $[6,17]$.

A.

\section{$\mathrm{Mg}^{2+}(\mathrm{mM})$}

calculated
$\mathrm{Mg}^{2+}(\mathrm{mM})$
measured
B.

$\begin{array}{ll}\mathrm{Mg}^{2+}(\mathrm{mM}) & \mathrm{Ca}^{2+}(\mu \mathrm{M}) \\ \text { calculated } & \text { measured }\end{array}$

$\mathrm{NoCa}{ }^{2+} \quad \mathrm{Ca}^{2+}$

$0.2 \quad 7.5$



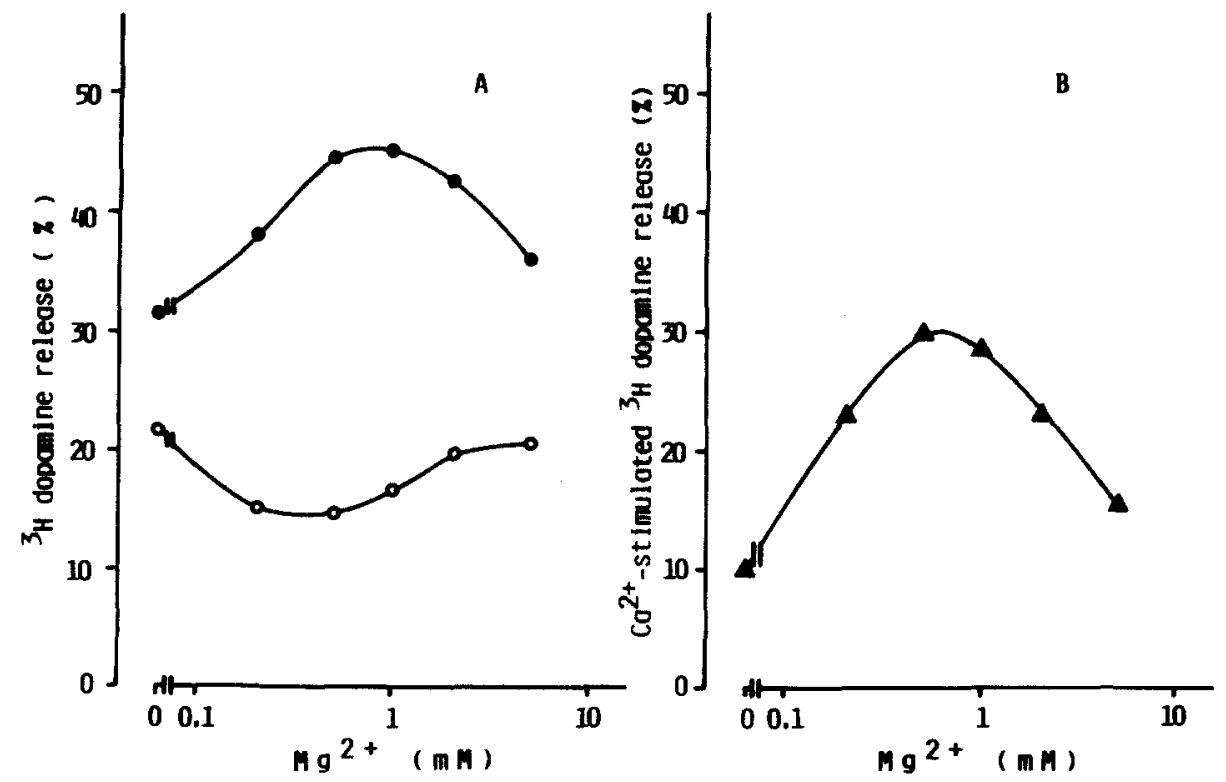

Fig. 1. Effects of various concentrations of free $\mathrm{Mg}^{2+}$ on exocytosis from $\alpha$-toxin-permeabilized PC12 cells. Preloaded PC12 cells were permeabilized with $\alpha$-toxin $(300 \mathrm{HU} / \mathrm{ml})$ in KG buffer (see Table I) in the absence or presence of the indicated concentrations of free $\mathrm{Mg}^{2+}$ for $30 \mathrm{~min}$ at $30^{\circ} \mathrm{C}$. The medium was exchanged for a fresh one containing either no $\mathrm{Ca}^{2+}$ or $8 \mu \mathrm{M}$ free $\mathrm{Ca}^{2+}$ plus the amounts of free $\mathrm{Mg}^{2+}$ given at the abscissa (A). A gives the percent of dopamine released in the absence (open symbols) or presence (closed symbols) of $\mathrm{Ca}^{2+}, \mathrm{B}$ the difference of the two curves in A. Values are the mean of two samples. The experiment was repeated 8 times with similar results.

First, at concentrations between 0.2 and $1 \mathrm{mM}$ it slightly lowered the basal release of $\left[{ }^{3} \mathrm{H}\right]$ dopamine in the absence of $\mathrm{Ca}^{2+}$ (Fig. 1). Second, $\mathrm{Mg}^{2+}$ drastically enhanced $\mathrm{Ca}^{2+}$-stimulated catecholamine release between 0.2 and $1 \mathrm{mM}$ free $\mathrm{Mg}^{2+}$ (Fig. 1A, B). In different experiments 0.2 and $1 \mathrm{mM}$ free $\mathrm{Mg}^{2+}$ increased the stimulated dopamine release 1.8 fold \pm 0.4 (S.D., $n=5$ ) and 2.8 fold \pm 0.6 (S.D., $n=6$ ), respectively. Free $\mathrm{Mg}^{2+}$ concentrations above $2 \mathrm{mM}$ were less potent, but the effects never dropped to values obtained in the absence of $\mathrm{Mg}^{2+}$ (Fig. 1A, B). An inhibitory action of higher $\mathrm{Mg}^{2+}$ concentrations was also reported for electrically permeabilized adrenal chromaffin cells [15]. If $\mathrm{Mg}^{2+}$ was absent during the 30 min preincubation with $\alpha$-toxin its effects on basal or $\mathrm{Ca}^{2+}$ stimulated release were less pronounced (not shown).

In order to find out whether soluble cytoplasmic proteins are involved in the effects of $\mathrm{Mg}^{2+}$ the experiments were also performed with SLO-permeabilized cells. In contrast to $\alpha$-toxin where only molecules up to $1000 \mathrm{Da}$ can escape during poration, SLO-permeabilized cells loose soluble cytoplasmic proteins as well [3-5, 9]. However, since in SLO-permeabilized cells $\mathrm{Mg}^{2+}$ still enhances $\mathrm{Ca}^{2+}$-stimulated $\left[{ }^{3} \mathrm{H}\right]$ dopamine release (Table II), cytoplasmic proteins are probably not involved in the effects of $\mathrm{Mg}^{2+}$. In this kind of experiment 0.2 and $1 \mathrm{mM}$ free $\mathrm{Mg}^{2+}$ increased the stimulated release $2.7 \pm 1$ and $3.1 \pm 1.1$ fold, respectively (S.D., $n=4$ ). It should be noted that 
TABLE II

EFFECTS OF VARIOUS CONCENTRATIONS OF FREE $\mathrm{Mg}^{2+}$ ON EXOCYTOSIS FROM SLOPERMEABILIZED PC12 CELLS

Preloaded PC12 cells were incubated with SLO $(60 \mathrm{HU} / \mathrm{ml})$ in KG buffer without divalent cations for 5 min at $0^{\circ} \mathrm{C}$. The buffer was replaced by a fresh one containing the given amounts of free $\mathrm{Mg}^{2+}$ but no $\mathrm{Ca}^{2+}$ and the cells were incubated for $20 \mathrm{~min}$ at $30^{\circ} \mathrm{C}$. Then the buffer was exchanged for a fresh one containing either no $\mathrm{Ca}^{2+}$ or $8 \mu \mathrm{M}$ free $\mathrm{Ca}^{2+}$ plus the amounts of $\mathrm{Mg}^{2+}$ given. Values are the mean of two samples. Five different experiments gave similar results.

\begin{tabular}{|c|c|c|c|}
\hline \multirow[t]{2}{*}{$\mathrm{Mg}^{2+}(\mathrm{mM})$} & \multicolumn{3}{|c|}{$\left[{ }^{3} \mathrm{H}\right]$ Dopamine release $(\%)$} \\
\hline & Basal & $\mathrm{Ca}^{2+}$-stimulated & Net release \\
\hline no & 35 & 44.5 & 9.5 \\
\hline 0.2 & 27.5 & 46.7 & 19.2 \\
\hline 0.5 & 28.8 & 48.4 & 19.5 \\
\hline 1 & 33.7 & 53.4 & 19.7 \\
\hline
\end{tabular}

in SLO-permeabilized cells lower amounts of free $\mathrm{Mg}^{2+}$ increased the stimulated release which may be due to the loss of $\mathrm{Mg}^{2+}$-binding material or other factors involved (compare Fig. 1 and Table II).

The improvement of the stimulated release by $\mathrm{Mg}^{2+}$ is not due to exchange of $\mathrm{Ca}^{2+}$ from intracellular stores or binding sites. In permeabilized PC12 or RIN A2 (a tumour cell line derived from a rat insulinoma) cells concentrations up to $1 \mathrm{mM}$ free $\mathrm{Mg}^{2+}$ neither increase nor decrease the free $\mathrm{Ca}^{2+}$ concentration as detected by $\mathrm{a} \mathrm{Ca}^{2+}$-sensitive electrode [12]. Furthermore the decrease of the basal release due to $\mathrm{Mg}^{2+}$ also argues against a liberation of $\mathrm{Ca}^{2+}$ from intracellular stores or proteins. Finally, the high capacity of the chelators present in the KG buffer would not allow changes in the free $\mathrm{Ca}^{2+}$ concentrations.

In PC12 cells exocytosis was reported to be inhibited by GTPS (guanosin $5^{\prime}-O$-(3-thio-triphosphate)) in the presence of free $\mathrm{Mg}^{2+}$. This inhibition is probably due to a pertussis toxin-sensitive GTP-binding protein [2]. Activation of G-proteins depends on the supply of free $\mathrm{Mg}^{2+}$ in the millimolar range [2]. Pretreatment of $\mathrm{PC12}$ cells with either pertussis toxin or cholera toxin failed to substantially alter the effects of $\mathrm{Mg}^{2+}$ on the basal or $\mathrm{Ca}^{2+}$-stimulated exocytosis. This indicates that the effects of $\mathrm{Mg}^{2+}$ reported here are unlikely mediated by G-proteins.

Taking these findings together it can be assumed that the effects of millimolar concentrations of free $\mathrm{Mg}^{2+}$ on exocytosis are attributed to binding of $\mathrm{Mg}^{2+}$ at the interacting membranes. This may reduce their negative surface charges and subsequently facilitates $\mathrm{Ca}^{2+}$-induced membrane fusion. Another possibility to explain the results would be that similar to the situation seen with charged liposomes [10] $\mathrm{Ca}^{2+}$ binding is increased in contacting membranes in the presence of an excess of free $\mathrm{Mg}^{2+}$.

We would like to thank G. Dayanithi and J.J. Nordmann for communicating us their results before publication. We are indebted to M. Rudolf for expert technical 
assistance. This work was supported by the Deutsche Forschungsgemeinschaft ( $\mathrm{Gr}$ 681, 2-3) and by the state of Baden-Württemberg (Landesforschungsschwerpunkt 32)

1 Ahnert-Hilger, G., Bhakdi, S. and Gratzl, M., Minimal requirements for exocytosis. A study using PC 12 cells permeabilized with staphylococcal alpha-toxin, J. Biol. Chem., 260 (1985) 12730-12734.

2 Ahnert-Hilger, G., Bräutigam, M. and Gratzl, M., $\mathrm{Ca}^{2+}$-stimulated catecholamine release from alphatoxin permeabilized PC 12 cells: biochemical evidence for exocytosis and its modulation by proteinkinase C and G-proteins, Biochemistry, 26 (1987) 7842-7858.

3 Ahnert-Hilger, G., Bader, M.F., Bhakdi, S. and Gratzl, M., Introduction of macromolecules into bovine adrenal medullary chromaffin cells and rat pheochromocytoma cells ( $\mathrm{PC} 12$ ) by permeabilization with streptolysin $\mathrm{O}$ : inhibitory effect of tetanus toxin on catecholamine secretion, J. Neurochem., 52 (1989) $1751-1758$.

4 Ahnert-Hilger, G., Weller, U., Dauzenroth, M.E., Habermann, E. and Gratzl, M., The tetanus toxin light chain inhibits exocytosis, FEBS Lett., 242 (1989) 245-248.

5 Ahnert-Hilger, G., Mach. W., Föhr, K.J. and Gratzl, M., Poration by alpha-toxin and streptolysin $\mathrm{O}-$ an approach to analyze intracellular processes. In A.M. Tartakoff (Ed.), Vesicular Transport Methods in Cell Biology, Vol. 31, Academic Press, New York, 1989.

6 Ammann, D., Bührer, T., Schäfer, U., Müller, M. and Simon, W., Intracellular neutral carrier-based $\mathrm{Ca}^{2+}$ microelectrode with subnanomolar detection limit, Pflügers Arch., 409 (1987) 223-228.

7 Bader, M.F., Thiersé, D., Aunis, D., Ahnert-Hilger, G. and Gratzl, M., Characterization of hormone and protein release from alpha-toxin permeabilized chromaffin cells in primary culture, J. Biol. Chem., 261 (1986) 5777-5783.

8 Bhakdi, S., Roth, M., Sziegoleit, A. and Tranum-Jensen, J., Isolation and identification of two hemolytic forms of streptolysin O, Infect. Immun., 46 (1984) 394400.

9 Bhakdi, S. and Tranum-Jensen, J., Damage to mammalian cells by proteins that form transmembrane pores, Rev. Physiol. Biochem. Pharmacol., 107 (1987) 147-223.

10 Ekerdt, R. and Papahadjopoulos, D., Intermembrane contact affects calcium binding to phospholipid vesicles, Proc. Natl. Acad. Sci. U.S.A., 79 (1982) 2273-2277.

11 Flodgaard, H. and Fleron, P., Thermodynamic parameters for the hydrolysis of inorganic pyrophosphate at $\mathrm{pH} 7.4$ as a function of $\left(\mathrm{Mg}^{2+}\right),\left(\mathrm{K}^{+}\right)$and ionic strength determined from equilibrium studies of the reaction. J. Biol. Chem., 249 (1974) 3465-3474.

12 Föhr, K.J., Scott, J., Ahnert-Hilger, G. and Gratzl, M., Characterization of the inositol-1,4,5-trisphosphate induced calcium release from permeabilized endocrine cells and its inhibition by decavanadate and parahydroxymercuribenzoate, Biochem. J., 262 (1989) 83-89.

13 Gilman, A., G-proteins: transducers of receptor-generated signals, Annu. Rev. Biochem., 56 (1987) 615-649.

14 Greene, L. and Tischler, A., PC 12 phaeochromocytoma cultures in neurobiological research, Adv. Cell Neurobiol., 3 (1982) 373-407.

$15 \mathrm{Knight,} \mathrm{D.} \mathrm{and} \mathrm{Baker,} \mathrm{P.,} \mathrm{Calcium-dependence} \mathrm{of} \mathrm{catecholamine} \mathrm{release} \mathrm{from} \mathrm{adrenal} \mathrm{medullary} \mathrm{cells}$ after exposure to intense electric fields, J. Membr. Biol., 68 (1982) 107-140.

16 Lind, I., Ahnert-Hilger, G., Fuchs, G. and Gratzl, M., Purification of alpha-toxin from staphylococcus aureus and application to cell permeabilization, Anal. Biochem., 164 (1987) 84-89.

17 Sillen, L. and Martell, A., Stability constants of metal-ion complexes, The Chemical Society, London, 1971, Suppl. 1, Special Publication No. 25.

I8 Simon, W., Ammann, D., Oehme, M. and Morf, W.. Ca ${ }^{2+}$ selective electrodes, Ann. N.Y. Acad. Sci., 307 (1978) 52-70. 